Editorial

\title{
Acknowledgment to Reviewers of IoT in 2021
}

\section{IoT Editorial Office}

Citation: IoT Editorial Office.

Acknowledgment to Reviewers of

IoT in 2021. IoT 2022, 3, 122.

https://doi.org/10.3390/iot3010007

Published: 28 January 2022

Publisher's Note: MDPI stays neutral with regard to jurisdictional claims in published maps and institutional affiliations.

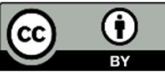

Copyright: $\odot 2022$ by the author. Licensee MDPI, Basel, Switzerland.

This article is an open access article distributed under the terms and conditions of the Creative Commons Attribution (CC BY) license (https://creativecommons.org/licenses/by/4.0/).
MDPI AG, St. Alban-Anlage 66, 4052 Basel, Switzerland

Rigorous peer-reviews are the basis of high-quality academic publishing. Thanks to the great efforts of our reviewers, IoT was able to maintain its standards for the high quality of its published papers. Thanks to the contribution of our reviewers, in 2021, the median time to first decision was 15 days and the median time to publication was 39 days. The editors would like to extend their gratitude and recognition to the following reviewers for their precious time and dedication, regardless of whether the papers they reviewed were finally published:

Alessandro Costantini
Alfonso Rodríguez
Anas Fattouh
Anastasija Collen
Antonio Puliafito
Benoit Parrein
Birhanu Belay
Carlos Muñoz-Poblete
Carolina Del-Valle-Soto
David Melendi
Dejan Drajic
Deokwoo Lee
Dimitris Kogias
Domenico Ursino
Dora M. Ballesteros
Emine Sezer
Emira Mharouech
Evangelos Sakkopoulos
Farhan Amin
Francesco Bergadano
Francesco Raffa
Francisco Bulnes
Georgios Tsaramirsis
Hasan Mahmood Aminul Islam
Hessam Golmohamadi
Il Dong Yun
Iyad Lahsen-Cherif
Jesús Ángel Román Gallego
Jin-Gyun Chung
Danang

